\title{
Estrogen Receptors in Human Breast Cancer
}

\author{
WILLIAM L. MCGUIRE \\ From the Department of Physiology and Medicine, University of Texas \\ Medical School at San Antonio, San Antonio, Texas 78229
}

A B S T R A C T Specific quantitative techniques have been used to measure the cytoplasmic estradiol-binding protein (EBP) in human mammary carcinoma tissue specimens. Sucrose gradient centrifugation reveals EBP to sediment at $8 \mathrm{~S}$ and $4 \mathrm{~S}$. Variable quantities of nonspecific estradiol binding occurs in the $4 \mathrm{~S}$ region of the sucrose gradient necessitating controls to insure specificity of the estradiol protein interaction.

Using dextran-coated charcoal to separate bound from free estradiol Scatchard analysis finds the dissociation constant of the estradiol EBP interaction to be $\sim 2.6 \times$ $10^{-10} \mathrm{M}$, indicative of the very high affinity of the ligand for the EBP. Quantitation of EBP sites in 64 primary and metastatic human breast tumors demonstrates a continuous spectrum of values from 0 to $612 \mathrm{fmol}$ per $\mathrm{mg}$ of cytoplasmic protein. Specific $8 \mathrm{~S}$ binding in the sucrose gradient centrifugation was not detected in specimens containing less than 9.0 fmol EBP per mg cytoplasmic protein.

Since data from animal breast tumors and preliminary evidence from human breast tumors indicates an excellent correlation between the presence of abundant tumor EBP and endocrine-induced breast cancer regressions, precise quantitation of EBP in all human primary tumors may prove to be an excellent prognosticator of endocrine therapy in metastatic breast cancer.

\section{INTRODUCTION}

Approximately one-third of patients with metastatic breast cancer will respond to ovariectomy, adrenalectomy, or hypophysectomy with objective evidence of tumor regression (1-3). Experiments in this laboratory with rat mammary tumors (4-6) and preliminary data in human patients (7) indicate that tumors which contain appreciable cytoplasmic estradiol-binding protein $(\mathrm{EBP})^{1}$ regress after endocrine ablation therapy whereas tumors

Received for publication 13 June 1972 and in revised form 29 August 1972.

${ }^{1}$ Abbreviations used in this paper: DCC, dextran-coated charcoal ; EBP, estradiol-binding protein; $\mathrm{E}_{2}$, estradiol; $\mathrm{Kd}$, dissociation constant. without EBP fail to respond. Many investigators have recently attempted to directly or indirectly detect the presence of EBP in human breast tumor specimens (713). Except for two series $(9,13)$ none of these attempts have resulted in an actual quantitation of the number of specific estradiol-binding sites per unit of tissue.

In order to eventually correlate the absolute level of EBP in tumor specimens with the biological behavior of the tumors as well as the response to endocrine therapy, specific quantitative assays for EBP have been used in human breast cancer tissue. Earlier data derived from animal breast tumors using less sensitive methodology led to the suggestion that EBP was present or absent in an all or none fashion (4). I now report that in both primary and metastatic human breast tumors, EBP is present in a broad concentration range from zero to very high levels expressed as estradiol-binding sites per milligram of cytoplasmic protein.

\section{METHODS}

Specimens were obtained from Wilford Hall Air Force Hospital, San Antonio, Tex. (Dr. W. Kemmerer), Memorial Hospital, New York (Dr. A. Fracchia), and the Ochsner Foundation, New Orleans, La. (Dr. A. Segaloff). Tissues were excised and placed directly into liquid nitrogen. They were then put into plastic vials and kept in freezers $\left(-20^{\circ} \mathrm{C}\right.$ to $\left.-76^{\circ} \mathrm{C}\right)$. For shipping they were put in an insulated box filled with dry ice and sent air mail-special delivery to San Antonio where they were kept in a Revco freezer (Revco, Inc., West Columbia, S. C.) $\left(-76^{\circ} \mathrm{C}\right)$ until assay. This procedure was successful in maintaining frozen tissue unless unusual shipping delays occurred. Tissues were thawed at $4^{\circ} \mathrm{C}$, then homogenized in a motor-driven glass homogenizer in $0.01 \mathrm{M}$ Tris- $\mathrm{HCl}, 0.0015 \mathrm{M}$ EDTA $\mathrm{pH} 7.4,2 \mathrm{ml}$ buffer per $\mathrm{g}$ tissue. The homogenate was then centrifuged at $160,000 \mathrm{~g}$ for $45 \mathrm{~min}$ to obtain the supernatant cytosol fraction. Protein was quantitated by the method of Lowry, Rosebrough, Farr, and Randall (14).

Sucrose gradients. All sucrose gradients were prepared in $0.01 \mathrm{M}$ Tris- $\mathrm{HCl}, 0.0015 \mathrm{M}$ EDTA $\mathrm{pH}$ 7.4. Gradients were prepared by layering $0.5 \mathrm{ml} 20 \%$ sucrose, $1.2 \mathrm{ml}$ each $16.25,12.5$, and $8.75 \%$ sucrose, and $0.5 \mathrm{ml} 5 \%$ sucrose in cellulose nitrate tubes and allowing diffusion in the cold for $18 \mathrm{~h}$. Examinations of fractions on the refractometer showed that the resultant gradient was linear except for 


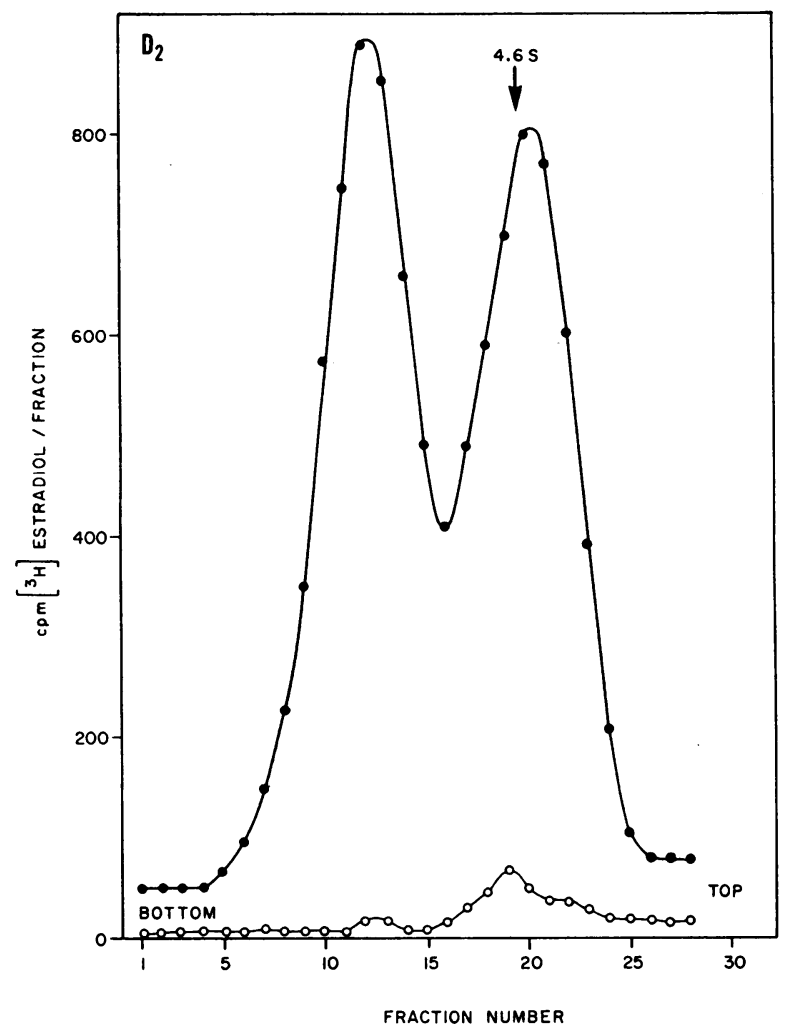

Figure 1 Sucrose gradient centrifugation of human mammary carcinoma cytosol with $(O)$, and without (๑) nonradioactive estradiol preincubation as described in the text.

the top $200 \mu \mathrm{l}$ which was gently removed and replaced with a $200 \mu 1$ sample just before centrifugation in a Beckman SW 56 rotor (Beckman Instruments, Inc., Fullerton, Calif.) at $44,000 \mathrm{rpm}$ for $15 \mathrm{~h}$. Each sample contained $1000 \mathrm{cpm}$ $\left[{ }^{14} \mathrm{C}\right]$ bovine serum albumin (15) as an internal marker. The $C^{14}$ peak provided a check of the quality of each gradient as well as a more precise sedimentation standard than achieved with the usual separate albumin gradient. After centrifugation, four drop fractions were collected and suspended in modified Brays solution (125 g naphthalene, 7.5 g 2,5-diphenyloxazole (PPO), $0.38 \mathrm{~g}$ 1,4-bis[2-(5phenyloxazolyl)]benzene (POPOP), 1 liter $p$-dioxane) for radioactivity measurement. Sedimentation values were determined according to Martin and Ames (16). Samples for gradient analysis were prepared by incubating $250 \mu 1$ of cytosol with $0.2 \mathrm{pmol}\left[{ }^{3} \mathrm{H}\right]$ estradiol, $96 \mathrm{Ci} / \mathrm{mmol},\left(\left[{ }^{3} \mathrm{H}\right] \mathrm{E}_{2}\right)$ for $60 \mathrm{~min}$ at $4^{\circ} \mathrm{C}$. Control cytosols were preincubated for $60 \mathrm{~min}$ at $4^{\circ} \mathrm{C}$ with $20 \mathrm{pmol}$ nonradioactive $17 \mathrm{~B}$-estradiol before adding the labeled estradiol. After the incubation the nonbound estradiol was removed by treatment with dextran-coated charcoal (DCC). $1 \mathrm{ml}$ of DCC suspension $(2.5 \mathrm{~g} /$ liter Norit $\mathrm{A}$ and $25 \mathrm{mg} /$ liter dextran in $0.01 \mathrm{M}$ Tris- $\mathrm{HCl} \mathrm{pH} \mathrm{8.0)} \mathrm{was} \mathrm{centrifuged} 10 \mathrm{~min}$ at $2000 \mathrm{~g}$ and the supernate discarded. The DCC pellet was resuspended directly into the cytosol and after $15 \mathrm{~min}$ was centrifuged $10 \mathrm{~min}$ at $2000 \mathrm{~g}$ leaving the supernate free of nonbound $\left[{ }^{3} \mathrm{H}\right] \mathrm{E}_{2}$. The treated cytosol was then applied to the sucrose gradient.

Saturation analysis with DCC. Cytosol was prepared as above and incubated $(200 \mu \mathrm{l})$ with increasing quantities of $\left.{ }^{3} \mathrm{H}\right] \mathrm{E}_{2}(0.015-0.2 \mathrm{pmol})$ in duplicate for $18 \mathrm{~h}$ at $4^{\circ} \mathrm{C} .1 \mathrm{ml}$ of DCC suspension was then added and after $30 \mathrm{~min}$ at $4^{\circ} \mathrm{C}$ the mixture was centrifuged for $10 \mathrm{~min}$ at $2000 \mathrm{~g}$. The supernate containing the bound $\left[{ }^{3} \mathrm{H}\right]$ estradiol was added to a BBS-3 (Beckman Instruments, Inc.) cocktail for scintillation counting. The data were analyzed according to Scatchard (17). The results were expressed as the number of femtomoles of $\left[{ }^{3} \mathrm{H}\right] \mathrm{E}_{2}$ specifically bound/milligram of cytosol protein.

\section{RESULTS}

Of all the available methods for demonstrating EBP, sucrose gradient centrifugation is the most specific. The presence of an 8-10S peak of estradiol radioactivity unequivocally indicates the presence of EBP in a tumor cytosol. In Fig. 1 a representative human breast cancer cytosol- $\left[{ }^{3} \mathrm{H}\right] \mathrm{E}_{2}$ sucrose centrifugation is displayed. The specific $8-10 \mathrm{~S}$ peak can be seen near the bottom of the gradient and the 4-5S peak near the top. Whereas a 8-10S peak always represents specific EBP, a 4-5S peak could represent nonspecific $\left[{ }^{3} \mathrm{H}\right] \mathrm{E}_{2}$ binding, so a preincubation of an identical cytosol with a 100 -fold excess of unlabeled estradiol is always included. Fig. 1 shows that the unlabeled estradiol has predictably eliminated all of the 8-10S peak of $\left[{ }^{3} \mathrm{H}\right] \mathrm{E}_{2}$, but in addition has eliminated the majority of the 4-5S peak. Therefore, in this particular cytosol, the majority of the 4-5S peak represents specific $\left[{ }^{3} \mathrm{H}\right] \mathrm{E}_{2}$ binding. Fig. 2 reveals a tumor cytosol which lacks an 8-10S peak but has an appreciable 4-5S peak. In this instance the $4-5 \mathrm{~S}$ peak is unaffected by nonradioactive estradiol preincubation. Hence, all of the

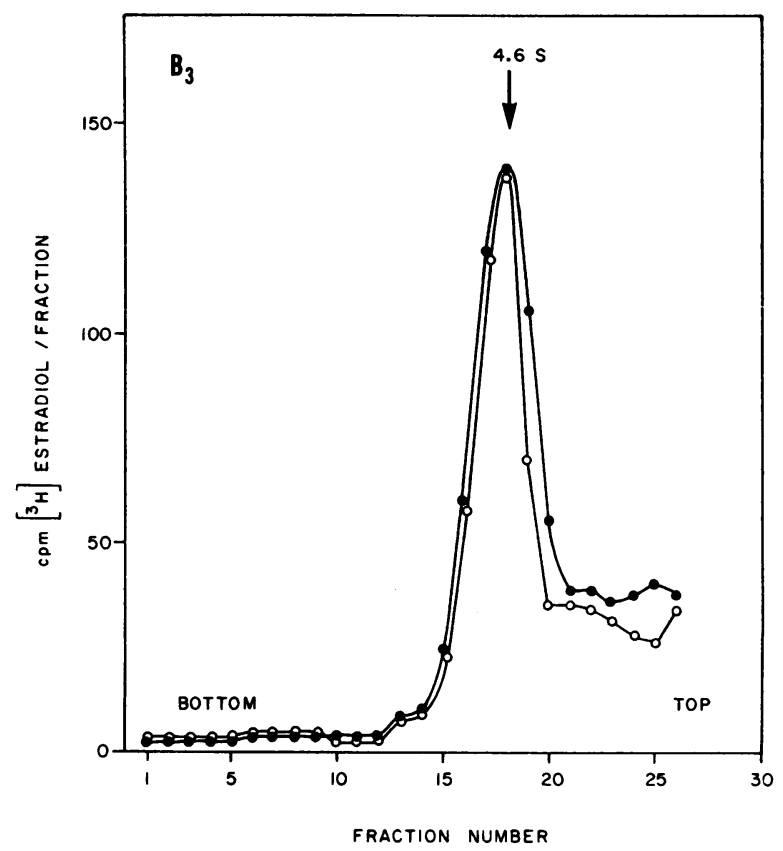

FIGURE 2 Sucrose gradient centrifugation of human mammary carcinoma cytosol with $(O)$ and without $(\bullet)$ nonradioactive estradiol as described in the text. 


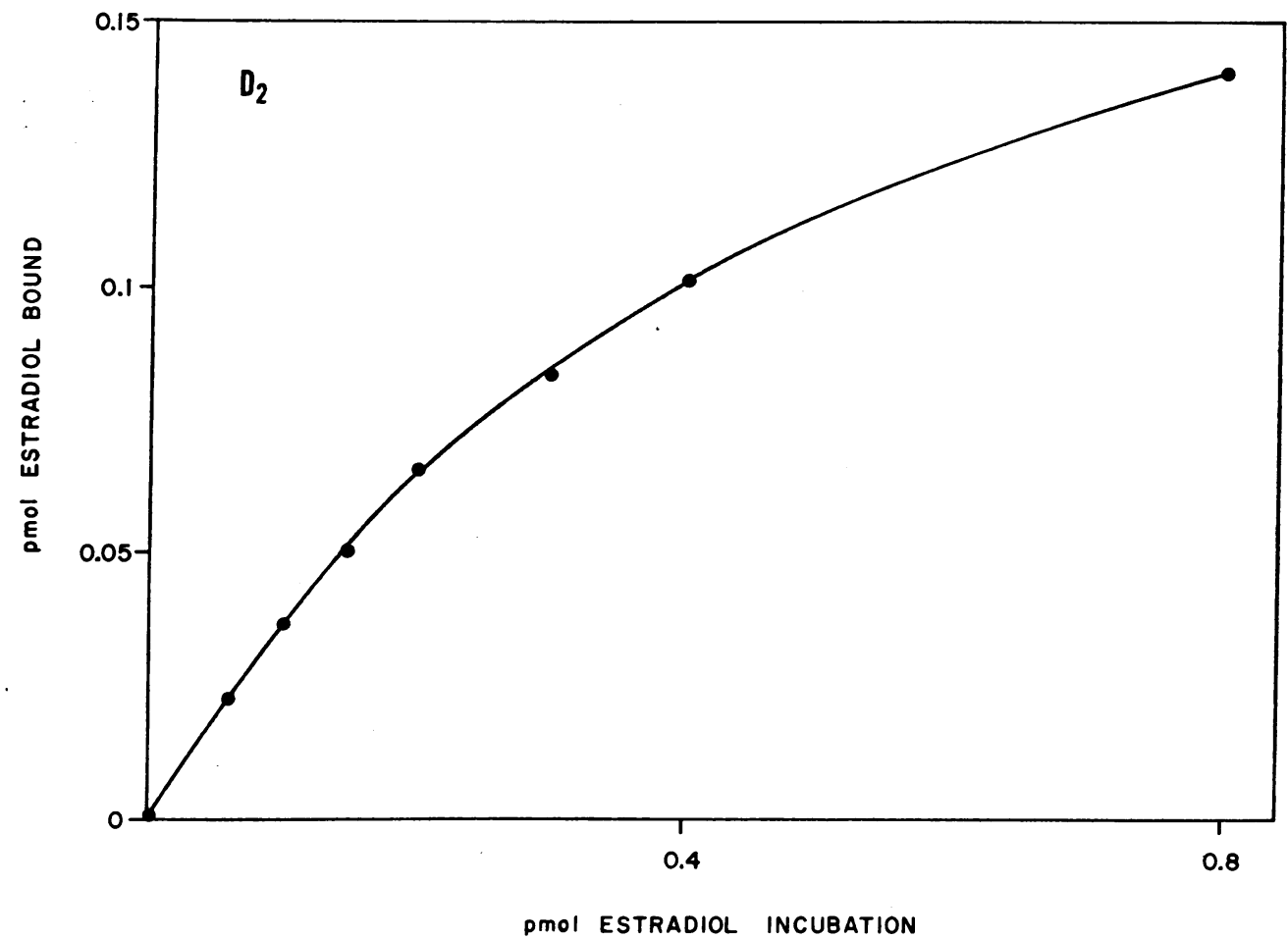

FIGURE 3 Binding of radioactive estradiol to human mammary carcinoma cytosol as determined by the DCC technique described in the text.

estradiol binding observed in this tumor cytosol is nonspecific and emphasizes the need for proof of specificity in measuring EBP.

$\mathrm{By}$ adding increasing quantities of $\left[{ }^{3} \mathrm{H}\right] \mathrm{E}_{2}$ to a constant amount of cytosol, the 8-10S and specific 4-5S binding sites could be saturated to yield the total number of EBP sites per milligram of cytoplasm protein. However, quantitative analysis by this method would be an enormous task and would not be practical for routine use. I recommend that the sucrose gradient be run on every tumor sample for two reasons: $(a)$ The qualitative proof of the presence of EBP (8-10S peak). (b) Evaluation of the specificity of $4-5 \mathrm{~S}$ binding which could be important and will be discussed later.

In order to quantitate EBP the DCC method originally described by Korenmann is used (9). The addition of DCC to a preincubated mixture of cytosol and $\left[{ }^{3} \mathrm{H}\right] \mathrm{E}_{2}$ quantitatively removes the nonbound $\left[{ }^{3} \mathrm{H}\right] \mathrm{E}_{2}$ and leaves the bound $\left[{ }^{3} \mathrm{H}\right] \mathrm{E}_{2}$ in the supernate for measurement. Since the $\left[{ }^{3} \mathrm{H}\right] \mathrm{E}_{2}$ left in the supernate may be bound to $\mathrm{EBP}$ or to nonspecific proteins, it is important to incubate cytosols with very low quantities of $\left[{ }^{3} \mathrm{H}\right] \mathrm{E}_{2}(<1 \times$ $10^{-8} \mathrm{M}$ ) to minimize nonspecific binding. Fig. 3 shows a representative DCC binding curve of human mammary carcinoma cytosol. The bound $\left[{ }^{3} \mathrm{H}\right] \mathrm{E}_{2}$ is plotted as a function of the total $\left[{ }^{3} \mathrm{H}\right] \mathrm{E}_{2}$ input. Usually, this method of data presentation is not adequate to accurately de- termine the saturation value so a Scatchard analysis is always performed as in Fig. 4. The data in Fig. 3 have been replotted, and the linear relationship that results indicates one class of binding sites. It is important to emphasize that at higher dose levels of $\left[{ }^{3} \mathrm{H}\right] \mathrm{E}_{2}$, nonspecific binding becomes appreciable and the Scatchard plot is no longer linear. In this cytosol there are $53 \mathrm{fmol}$ of EBP binding sites per $\mathrm{mg}$ cytosol protein. Another advantage of the Scatchard plot is that an estimate of the dissociation constant $(\mathrm{Kd})$ is readily obtained. This in turn is a reflection of the specificity of the cytosol- $\left[{ }^{3} \mathrm{H}\right] \mathrm{E}_{2}$ interaction since specific EBP- $\left[{ }^{3} \mathrm{H}\right] \mathrm{E}_{2}$ interactions yield $\mathrm{Kd}$ much lower than $1 \times 10^{-8} \mathrm{M}$ whereas nonspecific $\left[{ }^{3} \mathrm{H}\right] \mathrm{E}_{2}$ interactions yield $\mathrm{Kd}$ several orders of magnitude higher (low affinity binding). Fig. 4 reveals the $\mathrm{Kd}$ of this particular cytosol to be $2.6 \times 10^{-10} \mathrm{M}$. Using both the DCC assay and sucrose gradient centrifugation we have evaluated 64 human breast cancers. Table I reveals a range of values from 0 to $612 \mathrm{fmol} \mathrm{EBP} / \mathrm{mg}$ cytosol protein in 43 primary tumors. With the exception of the highest value, the numbers of sites fall in a rather continuous spectrum. As expected, an 8-10S peak is present in cytosols with the highest number of EBP sites.

In Table II are the data from 21 metastatic tumors. Again a wide continuous range of values can be seen with the highest EBP values associated with an 8-10S peak. Considering both Tables I and II, it appears that

Estrogen Receptors in Human Breast Cancer 


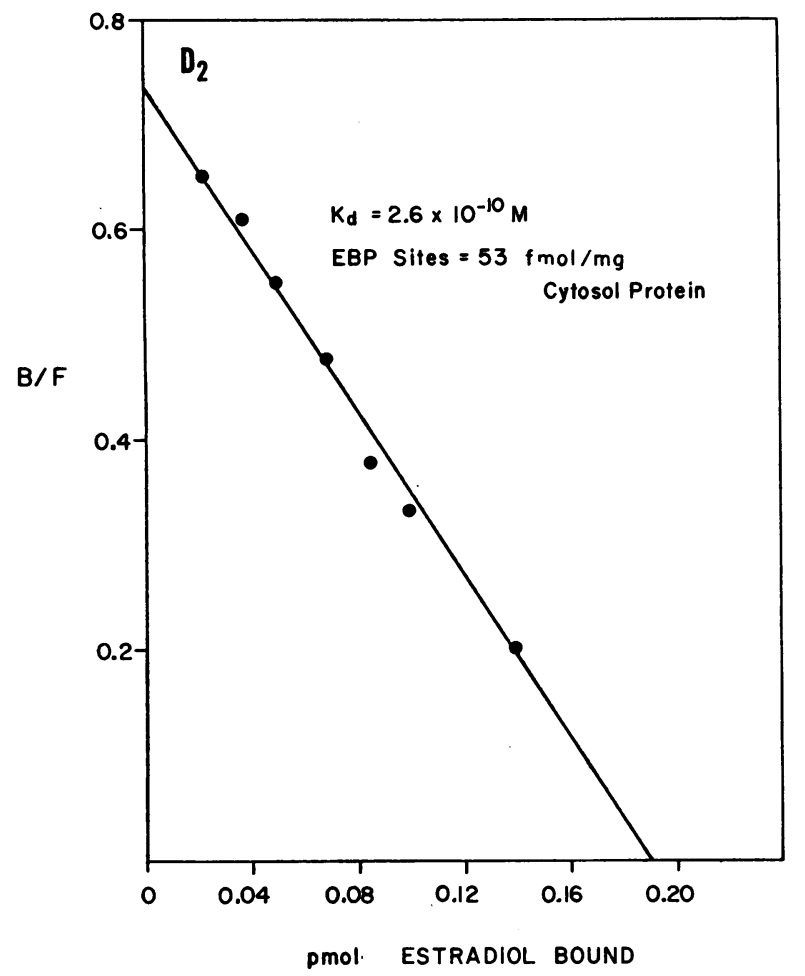

Figure 4 Scatchard analysis of the data in Fig. 3.

an EBP concentration of at least $9 \mathrm{fmol} / \mathrm{mg}$ cytosol protein is necessary to detect the $8-10 \mathrm{~S}$ peak by sucrose gradient centrifugation.

\section{DISCUSSION}

This report emphasizes the following two points: (a) The concentration of EBP in both primary and metastatic human mammary carcinoma varies over a wide range. Thus, an assay for EBP must be quantitative. (b) Nonspecific binding of $\left[{ }^{3} \mathrm{H}\right] \mathrm{E}_{2}$ by tumor cytosol may be considerable so it is essential to have independent checks and controls to insure the specificity of the observed binding. In a report to be published elsewhere, other possible methods of measuring human EBP were examined and Sephadex gel filtration and protamine sulfate precipitation were found to be unsatisfactory. The popular in vitro tissue slice uptake method is not quantitative and requires additional controls to insure specificity. The DCC method gives accurate quantitative data and the sucrose gradient centrifugation with and without nonradioactive estradiol preincubation gives ideal specificity proof. It could be argued that the sucrose gradient method is cumbersome and expensive and that the Kd derived from the DCC assay is sufficient proof of the specificity of the interaction. This may well turn out to be true but at present the gradient centrifugation is still necessary to evaluate $4-5 \mathrm{~S}$ binding. Steggles and King reported that a 4-5S EBP distinct from the usual 8-10S or salt-derived 4-5S form was present in uteri of mature rats (18). Furthermore, this 4-5S form disappeared after ovariectomy or hypophysectomy and thus could be very important in breast tumor response to endocrine ablation. We do not find this 4-5S form in the uteri of mature rats (19) but do find considerable specific 4-5S cytoplasmic binding in human breast tumors, so that until this issue is resolved it is necessary to assay 4-5S binding separately by sucrose gradient centrifugation.

Although it is not known what factors account for the wide range of EBP concentration, there are several possibilities. First, since tumors contain various cell types, the EBP concentration might be expected to vary inversely with the proportion of nonepithelial connective cells present. This is supported by the observation that although normal breast epithelial cells contain EBP, the abundance of nonepithelial cells in a random sample of normal breast prevents detection of specific EBP

TABLE I

Estrogen Receptors in Human Primary Mammary Carcinoma

\begin{tabular}{|c|c|c|}
\hline Code & EBP sites & $\begin{array}{l}\text { 8-10S } \\
\text { binding* }\end{array}$ \\
\hline \multicolumn{3}{|c|}{ fmol/mg cylosol protein } \\
\hline B & 612 & + \\
\hline $\mathrm{D}_{3}$ & 96.2 & + \\
\hline $\mathrm{K}_{1}$ & 78 & + \\
\hline $\mathrm{D}_{2}$ & 54 & + \\
\hline $\mathrm{Y}_{2}$ & 50 & + \\
\hline $\mathrm{E}_{1}$ & 42 & + \\
\hline $\mathrm{K}_{3}$ & 28.4 & + \\
\hline $\mathrm{T}_{2}$ & 20.8 & + \\
\hline $\mathrm{L}$ & 20.5 & ND \\
\hline $\mathrm{E}$ & 15.3 & 0 \\
\hline $\mathrm{S}$ & 11.3 & ND \\
\hline $\mathrm{T}_{1}$ & 9.8 & 0 \\
\hline$Z_{2}$ & 9.0 & + \\
\hline $\mathrm{N}$ & 8.0 & ND \\
\hline $\mathrm{C}_{1}$ & 6.2 & 0 \\
\hline $\mathrm{K}_{2}$ & 5.1 & 0 \\
\hline$Z$ & 4.9 & 0 \\
\hline $\mathrm{S}_{1}$ & 4.6 & 0 \\
\hline $\mathrm{J}_{3}$ & 4.4 & 0 \\
\hline $\mathrm{U}_{1}$ & 3.8 & 0 \\
\hline$F_{1}$ & 2.4 & 0 \\
\hline $\mathrm{K}$ & 1.3 & ND \\
\hline $\mathrm{P}_{2}$ & 1.0 & 0 \\
\hline $\mathrm{S}_{2}$ & 0.6 & 0 \\
\hline 19 Patients & 0.0 & 0 \\
\hline
\end{tabular}

* The + represents definite binding of $\left[{ }^{3} \mathrm{H}\right]$ estradiol in 8-10S region of the sucrose gradient centrifugation while 0 indicates a lack of such binding.

ND indicates not done. 
TABLE II

Estrogen Receptors in Human Metastatic Mammary Carcinoma

\begin{tabular}{|c|c|c|c|}
\hline Code & EBP sites & $\begin{array}{c}8-10 S \\
\text { binding* }\end{array}$ & $\begin{array}{l}\text { Site of } \\
\text { biopsy }\end{array}$ \\
\hline \multicolumn{4}{|c|}{$\begin{array}{c}\text { fmol,'mg } \\
\text { cylosol protein }\end{array}$} \\
\hline $\mathrm{H}_{1}$ & 185 & + & Breast \\
\hline $\mathrm{L}_{1}$ & 91 & + & Lymph node \\
\hline $\mathrm{R}_{1}$ & 46 & + & Breast \\
\hline $\mathrm{V}$ & 44 & ND & Ovary \\
\hline $\mathrm{N}_{1}$ & 28 & + & Breast \\
\hline$F_{2}$ & 11.6 & + & Lymph node \\
\hline $\mathrm{J}_{1}$ & 11.0 & 0 & Breast \\
\hline $\mathrm{G}_{1}$ & 9.4 & 0 & Breast \\
\hline$M_{1}$ & 9.0 & 0 & Lymph node \\
\hline$Y_{1}$ & 8.2 & 0 & Breast \\
\hline$V_{1}$ & 8.0 & 0 & Liver \\
\hline $\mathrm{D}_{1}$ & 7.0 & 0 & Liver \\
\hline$W_{1}$ & 5.0 & 0 & Bone \\
\hline $\mathrm{R}_{2}$ & 1.8 & 0 & Lymph node \\
\hline 7 Patients & 0 & 0 & \\
\hline
\end{tabular}

* The + represents definite binding of $\left[{ }^{3} \mathrm{H}\right]$ estradiol in the 8-10S region of the sucrose gradient centrifugation while 0 indicates a lack of such binding.

ND indicates not done.

$(9,12,13)$. However, this has been investigated in breast cancer specimens and no correlation exists between the histology of a tumor and its ability to bind estradiol $(8,10,13)$. Second, if we consider only the epithelial cells, the concentration of EBP may vary from cell to cell within a tumor since the measured EBP concentration is an integrated value for the whole tumor. This possibility could be tested by quantitative autoradiography. Finally, endogenous tumor estradiol must be considered since all available methods only measure EBP unoccupied by estradiol. Limited data on this point (9) indicates that endogenous estradiol can be measured in certain breast tumors which would produce variations in measurable EBP but since endogenous estradiol is present in exceedingly low levels only tumors with very low EBP would be significantly influenced.

In summary, specific quantitative assays for EBP in human breast cancer are now available. Data from such assays correlated with future clinical responses should lead to a better understanding of endocrine-induced breast cancer regression as well as a more rational approach to therapy.

\section{ACKNOWLEDGMENTS}

This work was supported by U. S. Public Health Service Grant CA-11378, American Cancer Society Grant BC-23B, and National Cancer Institute Contract G-72-3862.

\section{REFERENCES}

1. Huggins, C., and D. M. Bergenstal. 1952. Inhibition of human mammary and prostatic cancers by adrenalectomy. Cancer Res. 12 : 134 .

2. Kennedy, B. J. 1965. Hormone therapy for advanced breast cancer. Cancer. 18: 1551.

3. Lewison, E. F. 1965. Castration in the treatment of advanced breast cancer. Cancer. 18: 1558.

4. McGuire, W. L., and J. A. Julian. 1971. Comparison of macromolecular binding of estradiol in hormone-dependent and hormone-independent rat mammary carcinoma. Cancer Res. $31: 1440$.

5. McGuire, W. L., J. A. Julian, and G. C. Chamness. 1971. A dissociation between ovarian dependent growth and estrogen sensitivity in mammary carcinoma. Endocrinology. 89 : 969.

6. McGuire, W. L., K. Huff, A. Jennings, and G. C. Chamness. 1972. Mammary carcinoma: a specific biochemical defect in autonomous tumors. Science (Wash. D. C.) $175: 335$

7. Jensen, E. V., G. E. Block, S. Smith, K. Kyser, and E. R. DeSombre. 1971. Estrogen receptors and breast cancer response to adrenalectomy. Prediction of response in cancer therapy. Natl. Cancer Inst. Monogr. 34: 55.

8. Sander, S. 1968. The in vitro uptake of oestradiol in biopsies from 25 breast cancer patients. Acta Pathol. Microbiol. Scand. 74: 301.

9. Korenman, S. G., and B. A. Dukes. 1970. Specific estrogen binding by the cytoplasm of human breast carcinoma. J. Clin. Endocrinol. Metab. 30: 639.

10. Johansson, H., L. Terenius, and L. Thorén. 1970. The binding of estradiol-17 to human breast cancers and other tissues in vitro. Cancer Res. 30: 692.

11. James, F., V. H. T. James, A. E. Carter, and W. T. Irvine. 1971. A comparison of in vivo and in vitro uptake of estradiol by human breast tumors and the relationship to steroid excretion. Cancer Res. 31: 1268.

12. Hähnel, R., E. Twaddle, and A. B. Vivian. 1971. Estrogen receptors in human breast cancer. In vitro binding of estradiol by benign and malignant tumors. Steroids. $18: 681$.

13. Feherty, P., G. Farrer-Brown, and A. E. Kellie. 1971. Oestradiol receptors in carcinoma and benign disease of the breast: an in vitro assay. Br. J. Cancer. 25: 697.

14. Lowry, O. H., N. J. Rosebrough, A. L. Farr, and R. J. Randall. 1951. Protein measurement with the Folin phenol reagent. J. Biol. Chem. 193: 265.

15. Rice, R. H., and G. E. Means. 1971. Radioactive labeling of proteins in vitro. J. Biol. Chem. 246: 831.

16. Martin, R. G., and B. N. Ames. 1961. A method for determining the sedimentation behavior of enzymes: application to protein mixtures. J. Biol. Chem. 236: 1372.

17. Scatchard, G. 1949. The attractions of proteins for small molecules and ions. Ann. N. Y. Acad. Sci. 51: 660.

18. Steggles, A. W., and R. J. B. King. 1970. The use of protamine to study $\left[6,7-{ }^{8} \mathrm{H}\right]$ oestradiol-17B binding in rat uterus. Biochem. J. 118: 695 .

19. Chamness, G. C., and W. L. McGuire. 1972. Estrogen receptor in the rat uterus. Physiological forms and artifacts. Biochemistry. 11: 2466. 